\title{
Guidelines for selective radiological assessment of inversion ankle injuries
}

\author{
M G DUNLOP, T F BEATTIE, G K WHITE, G M RAAB, R I DOULL
}

\begin{abstract}
A prospective study was performed to establish definitive guidelines for selective use of radiography in the assessment of inversion ankle injuries. Five hundred patients were included, representing $3.2 \%$ of the workload of the department during the study period. There were 379 soft tissue injuries, 56 malleolar fractures, 40 avulsion fractures, 21 fractures at the base of the fifth metatarsal, and four calcaneal fractures. Multiple logistic regression identified distal fibular tenderness, age, and ability to bear weight as the most important clinical variables in predicting important fractures $(p<0.001)$.

A policy of requesting $x$ ray examination of only those patients with distal fibular tenderness or inability to bear weight or aged over 60, with a further proviso that no foot radiographs should be obtained, would produce a $60 \%$ reduction in ankle radiography in this centre without detriment to patient care.
\end{abstract}

\section{Introduction}

Radiography is widely used in the assessment of inversion ankle injuries presenting to accident and emergency departments. Ankle

\footnotetext{
Department of Accident and Emergency Medicine, Edinburgh Royal Infirmary, Edinburgh EH3 9YW

M G DUNLOP, MB, CHB, senior house officer

T F BEATTIE, FRCS, registrar

R I DOULL, FRCR, senior registrar in radiology

Scottish Cancer Trials Office, University of Edinburgh

G K WHITE, MSC, statistician

Medical Statistics Unit, University of Edinburgh

G M RAAB, MSC, lecturer
}

Correspondence to: Dr M G Dunlop, Surgical Paediatric Department, Western General Hospital, Edinburgh EH4 2XU. radiography accounts for roughly $10 \%$ of all $x$ ray examinations performed in accident departments ${ }^{12}$ yet shows a fracture in only $13 \%$ of cases..$^{3.5}$ A retrospective pilot study in this centre showed that $93 \%$ of patients with inversion ankle injuries underwent $x$ ray examination, with foot views included in $28 \%$, at a cost of $£ 30000$ a year. ${ }^{6}$

Clinicians and radiologists advocate selective radiography of ankle injuries, ${ }^{2-5}{ }^{7-11}$ but definitive guidelines based on sound clinical and statistical data have not been established. We carried out a large prospective study using computer based data analysis to satisfy this need.

\section{Patients and methods}

Five hundred consecutive patients presenting to the accident and emergency department of Edinburgh Royal Infirmary with inversion ankle injuries were entered into the study, permission for which had been obtained from the local ethical committee. The history and results of examination were documented in a proforma (figure). Every patient then underwent anteroposterior and lateral ankle radiography, and anteroposterior and oblique views of the foot were obtained. The patient was assessed by the casualty officer in the normal course of his duties. Each radiograph was reviewed by a single senior registrar in radiology, who did not have access to the clinical data.

Radiographic findings were subdivided into important (that is, malleolar or calcaneal) fractures, which require specific management, and other injuries requiring only symptomatic treatment, such as fracture at the base of the fifth metatarsal, avulsion fractures, and ligament tears. No attempt was made to identify major ankle instability, as this study was designed to discriminate only important fractures from other injuries.

The predictive value of each variable alone in discriminating between types of injury was assessed by simple logistic regression, and multivariate analysis was performed using multiple logistic regression. ${ }^{12}$

\section{Results}

Inversion ankle injuries accounted for $3 \cdot 2 \%$ of the total number of patients attending the department during the period of this study. Of the 500 patients 
in the study group, 278 were male and 222 female; they were aged 12-86 (mean 33.9) years. Of the injuries, 379 were soft tissue injuries; 40 avulsion fractures ( 36 of the apex of the lateral malleolus, two of the cuboid, and two of the talus); 21 fractures of the fifth metatarsal; 56 malleolar fractures ( 52 of the lateral malleolus alone and four bimalleolar); and four calcaneal fractures.

Analysis of the history identified only age $(p<0.002)$ and previous injury $(p<0.02)$ as being significantly related to the type of injury. All six variables noted at the examination influenced the type of injury $(p<0.001)$

Multiple logistic regression analysis considered all factors together in discriminating between important fractures and other injuries. The single most important clinical feature was the site of lateral tenderness. After this variable had been allowed for, the ability to bear weight and age also contributed to the prediction of a population highly likely to have a serious fracture. No further improvement resulted when additional features were added into the analysis once these three had been taken into account.

The risk of important fracture was eight times greater when tenderness was localised to the distal fibula or malleolus than when it was localised to the lateral collateral ligament (table I). Altogether $53(95 \%)$ malleolar fractures and $53(88 \%)$ of all the important fractures resulted in tenderness in this area. After adjustment for the site of tenderness the relative risk of an important fracture increased by a factor of 1.8 for each decade of the patient's age and by a factor of 5.4 if the patient was unable to bear weight. Twenty nine (48\%) of the patients with an important fracture, however, could walk on the injured ankle, and thus serious injury could not be excluded by using this variable alone. Tenderness over the base of the fifth metatarsal predicted a $43 \%$ chance of fracture of that bone.

TABLE I-Distribution of injury by site of lateral tenderness, age, and ability to bear weight $(n=499) \star$

\begin{tabular}{|c|c|c|c|c|c|c|c|}
\hline \multirow[b]{2}{*}{$\begin{array}{l}\text { Age } \\
\text { (years) }\end{array}$} & \multirow[b]{2}{*}{$\begin{array}{l}\text { Able to bear } \\
\text { weight }\end{array}$} & \multicolumn{6}{|c|}{ Injury } \\
\hline & & $\begin{array}{l}\text { Malleolar } \\
\text { fracture }\end{array}$ & $\begin{array}{l}\text { Calcaneal } \\
\text { fracture }\end{array}$ & $\begin{array}{l}\text { Fifth metatarsal } \\
\text { fracture }\end{array}$ & $\begin{array}{l}\text { Avulsion } \\
\text { fracture }\end{array}$ & $\begin{array}{l}\text { Soft tissue } \\
\text { injury }\end{array}$ & Total \\
\hline \multicolumn{8}{|c|}{ Distal fibular tenderness } \\
\hline$<40$ & $\left\{\begin{array}{l}\text { No } \\
\text { Yes }\end{array}\right.$ & $\begin{array}{r}10 \\
8\end{array}$ & $\begin{array}{l}0 \\
0\end{array}$ & $\begin{array}{l}0 \\
1\end{array}$ & $\begin{array}{l}0 \\
7\end{array}$ & $\begin{array}{r}29 \\
127\end{array}$ & $\begin{array}{r}39 \\
143\end{array}$ \\
\hline $40-60$ & $\left\{\begin{array}{c}\text { No } \\
\text { Yes }\end{array}\right.$ & $\begin{array}{r}7 \\
10\end{array}$ & $\begin{array}{l}0 \\
0\end{array}$ & $\begin{array}{l}0 \\
0\end{array}$ & $\begin{array}{l}0 \\
7\end{array}$ & $\begin{array}{r}7 \\
24\end{array}$ & $\begin{array}{l}14 \\
41\end{array}$ \\
\hline $60+$ & $\left\{\begin{array}{l}\text { No } \\
\text { Yes }\end{array}\right.$ & $\begin{array}{r}10 \\
8\end{array}$ & $\begin{array}{l}0 \\
0\end{array}$ & $\begin{array}{l}0 \\
0\end{array}$ & $\begin{array}{l}0 \\
2\end{array}$ & $\begin{array}{l}1 \\
4\end{array}$ & $\begin{array}{l}11 \\
14\end{array}$ \\
\hline Total & & $53(20 \%)$ & 0 & $1(1 \%)$ & $16(6 \%)$ & $192(73 \%)$ & $262(100 \%)$ \\
\hline \multicolumn{8}{|c|}{ Tenderness over lateral collateral ligament } \\
\hline$<40$ & $\left\{\begin{array}{l}\text { No } \\
\text { Yes }\end{array}\right.$ & $\begin{array}{l}1 \\
1\end{array}$ & $\begin{array}{l}0 \\
0\end{array}$ & $\begin{array}{l}0 \\
1\end{array}$ & $\begin{array}{l}2 \\
9\end{array}$ & $\begin{array}{r}9 \\
119\end{array}$ & $\begin{array}{r}12 \\
130\end{array}$ \\
\hline $40-60$ & $\left\{\begin{array}{l}\text { No } \\
\text { Yes }\end{array}\right.$ & $\begin{array}{l}0 \\
1\end{array}$ & $\begin{array}{l}0 \\
0\end{array}$ & $\begin{array}{l}0 \\
1\end{array}$ & $\begin{array}{l}0 \\
7\end{array}$ & $\begin{array}{r}4 \\
32\end{array}$ & $\begin{array}{r}4 \\
41\end{array}$ \\
\hline $60+$ & $\left\{\begin{array}{l}\text { No } \\
\text { Yes }\end{array}\right.$ & $\begin{array}{l}0 \\
0\end{array}$ & $\begin{array}{l}2 \\
0\end{array}$ & $\begin{array}{l}1 \\
1\end{array}$ & $\begin{array}{l}0 \\
3\end{array}$ & $\begin{array}{l}1 \\
5\end{array}$ & $\begin{array}{l}4 \\
9\end{array}$ \\
\hline Total & & $3(1 \cdot 5 \%)$ & $2(1 \%)$ & $4(2 \%)$ & $21(10 \cdot 5 \%)$ & $170(85 \%)$ & $200(100 \%)$ \\
\hline \multicolumn{8}{|c|}{ Tenderness over fifth metatarsal } \\
\hline$<40$ & $\left\{\begin{array}{l}\text { No } \\
\text { Yes }\end{array}\right.$ & $\begin{array}{l}0 \\
0\end{array}$ & $\begin{array}{l}0 \\
1\end{array}$ & $\begin{array}{l}1 \\
4\end{array}$ & $\begin{array}{l}1 \\
1\end{array}$ & $\begin{array}{l}1 \\
9\end{array}$ & $\begin{array}{r}3 \\
15\end{array}$ \\
\hline $40-60$ & $\left\{\begin{array}{l}\text { No } \\
\text { yo }\end{array}\right.$ & 0 & 0 & 1 & 0 & 0 & 1 \\
\hline $40-60$ & YYes & 0 & 0 & 5 & 1 & 4 & 10 \\
\hline $60+$ & $\{$ No & 0 & 1 & 0 & 0 & 1 & 2 \\
\hline & YYes & 0 & 0 & 5 & 0 & 1 & 6 \\
\hline Total & & 0 & $2(5 \%)$ & $16(43 \%)$ & $3(8 \%)$ & $16(43 \%)$ & $37(100 \%)$ \\
\hline
\end{tabular}

*Complete data not available for one patient.

\begin{tabular}{|ll|}
\hline History \\
1 & Age \\
2 & Sex \\
3 & Date and time of injury \\
4 & Date and time of presentation \\
5 & History of previous ankle injury \\
Examination \\
1 & Site of lateral tenderness: \\
& Supramalleolar \\
& Malleolar \\
& Inframalleolar \\
& Bnteroinferior to malleolus \\
2 & Presence of medial malleolar tenderness \\
3 & Degree of swelling \\
4 & Site of swelling (as site of lateral tenderness) \\
5 & Presence of bruising \\
6 & Ability to bear weight \\
& \\
\hline
\end{tabular}

Proforma used to collect assessment data.

\section{Discussion}

Analysis of the data collected in this study successfully identified patients at high risk of having an important fracture and provided clinical indications for radiography of inversion ankle injuries (table II). The minimal number of fractures that would be missed by using policy 1 could be further reduced by using policies $2-4$ but at the cost of performing more radiography. Any policy for selecting patients gives an overoptimistic result when evaluated on the population used to devise it, and so table II shows estimates, obtained by statistical methods, ${ }^{13}$ of the effect of these four policies on future similar populations. Clearly, adoption of any of the policies would produce a substantial reduction in radiography while missing a minimal proportion of important fractures. This study does not, however, provide firm evidence for the choice between policies because of the small number of fractures missed. If policy 4 was selected the number of fractures missed by the less conservative policies could be monitored, which might allow a further reduction in radiography proposed by policies 1,2 , and 3 .

Previous studies suggested that absence of swelling indicated that radiography was unnecessary, ${ }^{2} 9$ but this would have missed six of the 56 malleolar fractures $(11 \%)$ and two of the four calcaneal fractures in our population. This compares unfavourably with policy 4 , which would miss two of the malleolar fractures $(4 \%)$ and one calcaneal fracture. The proforma in this study, however, 
documented only the degree of lateral swelling, while previous surveys have shown that swelling at either malleolus may indicate a fracture of the opposite malleolus, and so the findings may not be strictly comparable. In addition, the previous studies did not document calcaneal fractures, which often present in the early period after injury with very little swelling.

Calcaneal fractures were not expected to present as inversion ankle injuries, and so the proforma was not designed to allow for specific calcaneal tenderness and deformity or to record a history of a fall from a height. Three of the four calcaneal fractures would have examination for only those patients with distal fibular or malleolar tenderness or inability to bear weight or aged over 60 , with a further proviso of "no foot views," would produce a reduction of 1400 examinations of 750 patients at a saving of $£ 15000$ a year without detriment to patient care. ${ }^{6}$

We are grateful to all the staff of the department and to Dr K Little for permission to study patients under his care. We are indebted to Mrs L Lockerbie for the design of the proforma and Mrs $M$ Wilson for typing the manuscript.

TABLE II-Effects of different policies for radiography of inversion ankle injuries. (Predicted percentages given in parentheses)

\begin{tabular}{lccc}
\hline Selection policy & $\begin{array}{c}\text { \% Of important fractures } \\
\text { examined radiologically }\end{array}$ & $\begin{array}{c}\text { \% Of patients with ankle } \\
\text { injury denied radiography } \\
\text { but having a fracture }\end{array}$ & $\begin{array}{c}\text { \% Of ankle radiographs } \\
\text { saved }\end{array}$ \\
\hline 1: Distal fibular tenderness & $88 \cdot 3(86 \cdot 9)$ & $1 \cdot 4(1 \cdot 5)$ & $40 \cdot 6$ \\
2: Policy 1+ age over 60 & $93 \cdot 3(92 \cdot 5)$ & $0 \cdot 8(0 \cdot 9)$ & $36 \cdot 4$ \\
3: Policy 1+ non-weight bearing & $95(92 \cdot 7)$ & $0 \cdot 6(0 \cdot 9)$ & $35 \cdot 4$ \\
4: Policy 1+age over 60+non-weight bearing & $95(94 \cdot 9)$ & $0.6(0 \cdot 6)$ & $32 \cdot 4$ \\
\hline
\end{tabular}

^At current level of $93 \%$ in this centre.

been missed by policy 1 and one by each of policies $2-4$. It is important to consider calcaneal fracture in patients presenting with an "ankle sprain," particularly the elderly. Careful elucidation of the mechanism of injury and accurate localisation of tenderness are crucial.

Foot radiography did not provide any information that would have altered the patients' management and so has no part to play in the assessment of inversion ankle injuries. A $28 \%$ reduction in radiography could therefore be achieved in this centre just by excluding foot views. Tenderness over the base of the fifth metatarsal has prognostic value in predicting fracture of that bone but indicates that radiography is required only if the patient has persistent symptoms suggesting non-union.

Inversion ankle injuries constitute an appreciable proportion of the workload of accident departments and associated radiological services. Previous studies of radiography in ankle injuries have been limited by small samples, and most did not entail thorough statistical analysis. ${ }^{2-4} 7.9$ Our study was based on a large population sample. In Edinburgh Royal Infirmary a policy of requesting $x$ ray

\section{References}

1 Warren RA, Ferguson DG. Why do accident and emergency doctors request $\mathrm{x}$-rays? Archives of Emergency Medicine 1984;3:143-50.

2 De Lacey GJ, Bradbrooke $\mathrm{S}$. Rationalising requests for $\mathrm{x}$-ray examination of acute ankle injuries. BrMed f 1979; i: 1597-8.

3 Vargish T, Clarke WR, Young RA, Jensen A. The ankle injury-indications for the selective use of X-rays. Injury 1983;6:507-12.

4 Brooks SC, Potter BT, Rainey JB. Inversion injuries of the ankle: the clinical assessment and radiographic review. BrMed f 1981;282:607-8.

Royal College of Radiologists Working Party. Radiography of injured arms and legs in eight accident and emergency units in England and Wales. Br Med F 1985;291:1325-8.

6 Scottish Home and Health Department. Charges for hospital private resident and non-residen patients. Appendix B. Edinburgh: SHHD, 1985. (Circular 1985(GEN) 13 .

7 Garfield JS. Is radiological examination of the twisted ankle necessary? Lancet 1960;ii:1167-9.

8 Cockshott WP, Jenkin JK, Pui M. Limiting the use of routine radiography for acute ankle injuries. Can Med Assoc f 1983;129:129-31.

9 Montague AP, McQuillan RF. Clinical assessment of apparently sprained ankle and detection of fracture. Injury 1985;16:545-6.

10 Brand DA, Frazier WH, Johlmepp WC, et al. A protocol for selecting patients with injured extremities who need x-rays. N Engl f Med 1982;306:333-9.

11 Goldberg B. Department of inappropriate investigations. Br Med f 1977;ii:1274-5.

12 Dixon WJ, ed. BMDP statistical software. Berkeley: University of California Press, 1981.

13 Copas JB. Regression, prediction and shrinkage. Fournal of the Royal Statistical Society series B 1983;45:311-54.

Accepted 16 June 1986)
Should children with infectious diseases such as mumps, chickenpox, and glandular fever be isolated during their illness?

A decision on whether to isolate depends on whether the patient is "infectious," the severity of illness that could result in others, and on the particular circumstances of the case(s). Mumps and chickenpox are usually most infectious shortly before the parotid swelling or rash (respectively) appears, and the chance of transmitting infection after a week or so is small. In contrast infectious mononucleosis is spread principally by saliva, commonly from asymptomatic carriers. Isolation in the family setting for infection transmitted mainly by respiratory droplets, such as mumps and chickenpox, generally does not prevent spread but may be considered when the risks are high-for instance, a newborn baby contracting whooping cough from a sibling. When deciding whether to isolate a child from school colleagues or the general public it is important to consider the morbidity and mortality that could result if infections are allowed to spread unnecessarily. Orchitis in adults and aseptic meningitis often complicate mumps and fulminating varicella pneumonia may occur in the immune compromised and occasionally in pregnant women. Owing to improved management there are increasing numbers of schoolchildren who are taking or have received immunosuppressing treatment for leukaemia. The dangers of infection should not be underestimated and a period of isolation at home or (if necessary) in hospital for childhood infections is usually warranted.-ERIC WALKER, lecturer in infectious diseases, Glasgow.

Benenson AS, ed. Control of communicable disease in man. 14th ed. American Public Health Association, 1985
One of my patients is convinced that his ulcerative colitis is caused by inhalation of a spray mount adhesive which he uses at work. This is a latex gum in a solution of alcoholic liquid and it contains 1,1,1 trichloroethane and the label on the aerosol can says that inhaling the contents can be harmful or fatal. Could there be any basis to this man's anxiety?

$1,1,1$ trichloroethane (methyl chloroform: $\mathrm{CH}_{3} \mathrm{CCl}_{3}$ ) is a commonly used volatile, chlorinated aliphatic solvent. In common with most solvents it is well absorbed through the lungs, particularly as an aerosol, and has anaesthetic properties. Absorption may therefore cause headache, drowsiness, dizziness, impairment of behavioural performance, and, in extreme cases, coma and death. ${ }^{1} 1,1,1$ trichloroethane is poorly metabolised by the human body and is only slowly excreted in the breath; thus it tends to accumulate. Deaths have all been associated with extremely high concentrations, but even minor disturbances are not usually found unless exposure is well above the current recommended exposure limit of 350 parts per million $\left(1900 \mathrm{mg} / \mathrm{m}^{3}\right) .1,1,1$ trichloroethane is a gastrointestinal irritant and cathartic when ingested but this route of absorption is unlikely to be important when dealing with aerosol sprays. Although trichloroethylene has been associated with pneumatosis cystoides intestinalis in one study, ${ }^{2}$ we can find no evidence linking related solvents with specific intestinal disease.-W R LEE (professor) and A R SCOTT (lecturer) in occupational health, Manchester.

1 Health and Safety Executive. 1,1,1, trichloroethane. London: HMSO, 1984. (Toxicity review 9.) 2 Yamagucii $\mathrm{K}$. Pneumatosis cystoides intestinalis and trichloroethylenc exposure. Am $\mathcal{I}$ (jastroenterol 1985; 10:753-7. 